\title{
STUDYING TOURISM WEBSITES AND THE EFFECTS OF ONLINE SOCIAL MEDIA
}

\author{
Hala Nabil Hilaly \\ Associate Professor, Tourism Studies Department \\ Faculty of Tourism and Hotels, Alexandria University
}

\begin{abstract}
During the past decade, information technology has significantly changed the way the tourism companies plans, controls and manages operations. For example, the increased use of Web 2.0, has gradually altering the industry structure and developing a whole range of opportunities and threats. Hence, the purpose of this study is to verify the impact of online social networks in raising the number of visitors to referenced websites as well as forecasting the total number of tourism websites visitors and social media referrals to better understand and evaluate the potential importance of this technology using time series analysis. This objective will be achieved through analyzing the pattern of visits to a sample of Egyptian tourism websites and the relationship between the total visits and those having the OSNs as referrals has been measured.

The data analyzed in this study were provided from the secondary data generated by Google Analytics (GA). The data collected consisted of the series of total visits of Egyptian websites and the contributions of these visits via social media referrals. The significance of the explanatory variable visits via social media referrals as well as the time period was addressed with a multiple regression. To forecast the total number of visits to the tourism websites the time series analysis approach as a non causal method has been used.

The results show that time and social media referrals have a significant influence on the total visits of tourism websites. Moreover, Egyptian tourism businesses should not only consider the presence and interaction on Facebook, Google+ and My space, they should also consider Media sharing platforms such as You Tube and Pinterest.
\end{abstract}

Keywords: Web 2.0, Travel 2.0, Online social networks, Tourism website, Facebook, Website evaluation,

\section{Introduction}

The strong competition in today's business environment means that tourism and hospitality businesses have to work hard to maintain and develop their competitiveness. The success of a business is affected on its ability to acquire and utilize updated information to support its management and marketing processes. Hence, Information Technology (IT) assists organization to manage information dynamically and influences business competitiveness through supporting decision makers to make appropriate investments and decisions (Law et al. 2009).

Information technology has significantly changed the way the tourism companies plans, controls and manages operations. It reshapes the fundamental structure of the industry and the entire process of developing, managing and marketing tourism products 
and destinations (Buhalis 1998, 2003; O’Connor1999; Buhalis and O’Connor 2005). The information communication technology (ICT) driven reengineering has gradually altering the industry structure and developing a whole range of opportunities and threats. Thus, strategic implementation of information technology and Internet become critical for all companies trying to survive in this new economy (Warnaby, et al, 2008).

The IT diffusion in the tourism and hospitality industries has recently increased at an unprecedented rate (Connolly \& Lee, 2006; Singh \& Kasavana, 2005). Researchers have stated that IT, by acting as a protector and enhancer, directly influences the experiences and behavior of tourists (Kim \& Ham, 2007; Singh, et al. 2006; Winata \& Mia, 2005).

In 2014, worldwide Internet users had reached 3 billion users with $7.9 \%$ growth rate and penetration rate $40.4 \%$ (percentage of population with internet). Nearly $75 \%$ ( 2.1 billion) of all internet users in the world live in the top 20 countries. China, the country with most users (642 million in 2014), while, U.S.A, Germany, France, UK and Canada have the highest penetration (Internet World Statistics).

The tremendous growth of the Internet has changed the way travel-related information is distributed and accessed (TIA, 2008; Werthner \& Klein, 1999; Xiang, et al. 2008). In recent years, "social media" are playing an increasingly important role in our daily life.

Social network penetration worldwide is ever increasing. In 2012, $63 \%$ of internet users are also social network users. In 2010, number of social network users were 0.97 billion. In 2015 it reaches 1.96 billion and it is expected to reach 2.44 billion by 2018 (The Statistics portal, 2015).

In travel and tourism, web sites such as TripAdvisor and Virtual Tourist have generated significant impact on the consumption and distribution of travel products (Xiang \& Gretzel, 2010). Since number of travelers participating into this new source of information and knowledge will significantly increase in the future, this will represent challenges to the established marketing practices of many tourism businesses and destinations (Blackshaw, 2006; Gretzel, 2006; Litvin, et al. 2008).

Web 2.0 could not remain unnoticed in activities related to people such as travel. The impact of Web 2.0 on tourism is important. Web 2.0 and social media also drive forward dramatic changes for tourism by turning the Internet into an enormous space of empowered consumers, social networking and collaboration. Tourists are consuming and producing information on tourism for others and individualizing information and services to reflect special interests (Werthner, et al. 2015).Web 2.0 allows readers to become real actors and be the centre of information exchange. Thus, the internet forces the reengineering of the entire process of producing and delivering tourism products (O'Connor 2003).

Most the previous researches focused on accessing the behavior, the usage, the content and the effects of Web 2.0 on the tourism websites. Hence, the online social networks have a vital role in raising the number of visitors to referenced websites.

The objective of this research is to verify the impact of online social networks in raising the number of visitors to referenced websites as well as forecasting the total number of tourism websites visitors as well as social media referrals to better understand and evaluate the potential importance of this technology in the future. This objective will be achieved through analyzing the pattern of visits to a sample of Egyptian tourism 
websites and the relationship between the total visits and those having the OSNs as referrals will be measured.

This paper is organized as follows. Section 2 briefly surveys websites in tourism, while section 3 will discuss social media in tourism. Section 4 and section5will describe research methodology and results respectively. Discussion will be presented in section 6 . Finally, section7 will conclude.

\section{Websites in Tourism}

Websites are incredibly important, mission critical, and cost effective marketing tools for businesses. Having a good website not only generates more business opportunities, but also enhances a company's image and supports the interactivity with both institutional and individual customers.

Good web design extends beyond technology and layout. It includes a wide range of content, design, ease of use, navigation and interactivity issues as well as overall impression. To increase web effectiveness, web designers should also consider network limitations, demographics, and the culture and soul of the site (Corfu \& Kastenholz, 2005). Metaphors and informativeness can also affect website effectiveness (Han \& Mills, 2006), whilst usability and content play a critical role in user satisfaction (Klausegger, 2005).

Web designers should also consider culture and language as a factor affecting the success of a website (Kale, 2006) and should cater for the needs of different types of online users (Han \& Mills, 2007; Shi, 2006; Williams \& Rattray, 2005; Williams, et al. 2006).

Websites are not only a marketing channel, but also a business platform. Successful websites must achieve a high hit and conversion rate, which is affected by consumer page clicking behavior, search engine optimization, content and web page management (Murphy, et al. 2006). By analyzing these activities, managers can better understand consumer behavior and thus gain a competitive advantage in conducting business (Kamuzora, 2006; Law, et al. 2007).

Website effectiveness has been defined subjectively and there is no consensus among researchers on its definition and operationalization. It has been suggested that expert judgments, consumer evaluation of revisits intentions and other network metrics like websites ranking, number of visits, time spent etc. can be used to evaluate tourism website effectiveness (Ip et al. 2011; Schmidt et al. 2008). Website effectiveness is also measured as intention to visit site, repeat visits, time spent, and number of visits and popularity of a website (Utkarsh, 2014).

\section{Social Media (Web 2.0) in Tourism}

Social media can be defined in different ways. According to Tuten (2008) socialmedia are determined by the creation of user-generated content, co-creation and commenting as well as sharing opinions on Web 2.0 applications. In this way, internet users can socialize online and share their own experiences. Types of Web 2.0 applications include among others file-sharing sites, blogs and social networks (Dooley et al. 2012).

Web 2.0 is also known as people-centric Web, participative web, or social media (O'Reilly, 2007). The key difference between the tradition web (Web 1.0) and Web 2.0 is 
that Web 1.0 has limited content creators with the huge majority of content for consumers; whereas Web 2.0 shifts its users from being passive viewers to being active creators (Reactive, 2007, Cormode \& Krishnamur, 2008). Web 2.0 in tourism, also referred as Travel 2.0, describes a new generation of travel websites with new technologies to encourage and facilitate a higher level of social interaction among travelers with very little technological knowledge (Casalo, et al. 2010; Kaplan and Haenlein, 2010). Social media have caused a shift from a read-only network to a readand-write culture (Gillin, 2009; Michelis and Schildhauer, 2012). Consequently, social media has become part of the everyday's life of millions of internet users (Kaplan and Haenlein, 2010).

According to e-Marketer (2012) 1.2 billion people worldwide used a social network site at least once per month in 2011. This number has increased to1.43 billion in 2012.

Social networks have gained high popularity, especially Facebook, Google + and MySpace, which are the large stones in this category (Kaplan and Haenlein, 2010).

Media sharing platforms, such as Flickr, YouTube and Pinterest, offer users the possibility to share predominately videos or photos. Media sharing platforms help people make content available to others, and to enable new ways of organizing photos and videos. However, successful implementation of media sharing platforms for marketing benefits also requires consumer engagement (Maurer \& Hinterdorfer, 2014).Obviously, from consumers' viewpoint using social media is of great value because of its richness as personal experiences and trustworthiness as electronic word-of-mouth (Gretzel, 2006; Litvin et al., 2008).

A recent report from PhoCus Wright (2009) showed that more than $80 \%$ of leisure travel consumers used travel related contents generated by users (UGC) on Web 2.0 during trip planning and travel decision making.

As social media become more widespread and popular, also social media marketing is continuously growing in importance. Social media provide a high level of interactive communication and user engagement which other media are lacking. Web 2.0 provides tourism companies with unprecedented opportunities to understand a market's reaction to their offering and subsequently feed this information in their product development and quality control process (Dellarocas, 2003). In response to the popularity of Web 2.0 among travelers, many travel related companies started to integrate these functions into their websites to enhance customers' travel information searching experience.

Therefore, social media can be very effective for marketing purposes. Charlesworth (2009) considers social media marketing as any online marketing strategy or tactic which uses social media as the medium for its communication, including advertising on social networks, viral marketing and social media optimization. Moreover, social media marketing is characterized by user control, freedom and peer-to-peer communication. These new rules should be taken into consideration by organizations in order to conduct successful social media marketing (Tuten, 2008). Consequently, an online marketing strategy of DMOs should not only consist of the corporate website, but should also include marketing activities on various online channels, in particular through social media (Inversini et al. 2012).

Social media marketing also offers great potential in the tourism industry as the internet is one of the primary sources where tourists seek and receive information 
regarding their holiday decisions (Parker, 2012), not only in the pre trip phase, but also in the planning stage and in the booking and consumption of the travel experience. The consumption of the tourism service is followed by a post-travel consisting of reflection and sharing of the travel experience (Milano 2011).

According to the Gallup Organization (2015) the internet is the second most important information source for EU citizens when deciding about holidays after recommendations of friends and colleagues. Contents generated by users (UGCs) play an important role in the tourism industry because the tourism product is intangible (Akehurst, 2009). The annual Country Brand Index (CBI) measuring attractiveness of countries stated that the Web had the highest importance (67\%) as channel to collect information about a tourism destination (CBI, 2007). On the other hand, the continuing growth of UGC's influence makes them perceived as more reliable as official sources for a tourist.

The potential tools for (HR) employees are for example, blogs, social networks (like Linkedin, facebook), virtual worlds, video platforms (e.g. YouTube) and Wikis (Kluemper and Rosen, 2009). Of all types of Web 2.0 applications, blogs in particular have increased rapidly for travel-related businesses as a medium to promote their products and to build customer relationships. Blogging is a non-traditional way to identify the image of a company and keeps in touch with consumers through creating lively and credible content on the website and facilitating continuous contact with customers.

In the Internet era, search engines play an important role in information searching (Ho \& Liu, 2005), and the Google search engine in particular is perceived to be the most important tool (Law \& Huang, 2006).

Many hotels, travel agencies, and DMOs have an account on social networking sites like MySpace.com and Facebook.com to help increase their web presence and establish high value links back to their homepages (Ettestad, 2008).Most companies have now penetrated the online social networking scene, offering direct links from their corporate Websites to Facebook and Twitter, believing that these tools can effectively promote brand awareness and support the creation of brand communities (Kaplan \& Haenlein, 2010). This trend of social media explosion is optimized by the effect of viral marketing which in turns may generate engagement, conversions, and revenue.

Recent statistics show that advertising spending on Facebook and MySpace is expected to reach high amounts with a significant portion of this spending directed towards building and maintaining a social network presence (Kaplan \& Haenlein, 2010).

Facebook try to occupy vertical markets through dedicated services or acquisitions of specialized companies as the social travel recommendations site next stop (Inside Facebook, 2015).

Facebook has become in few years the largest (in number of users) and the most widespread (in geographical terms) online social network in the world (Cozenza, 2010). The number of Facebook users reached 3 billion users in 2014 and had increased from 2012 to 2013 with an average of $22 \% .58 \%$ of the world population uses social networks and 56\% uses Facebook (Statistic brain, 2015). 


\section{The world map of social networks}

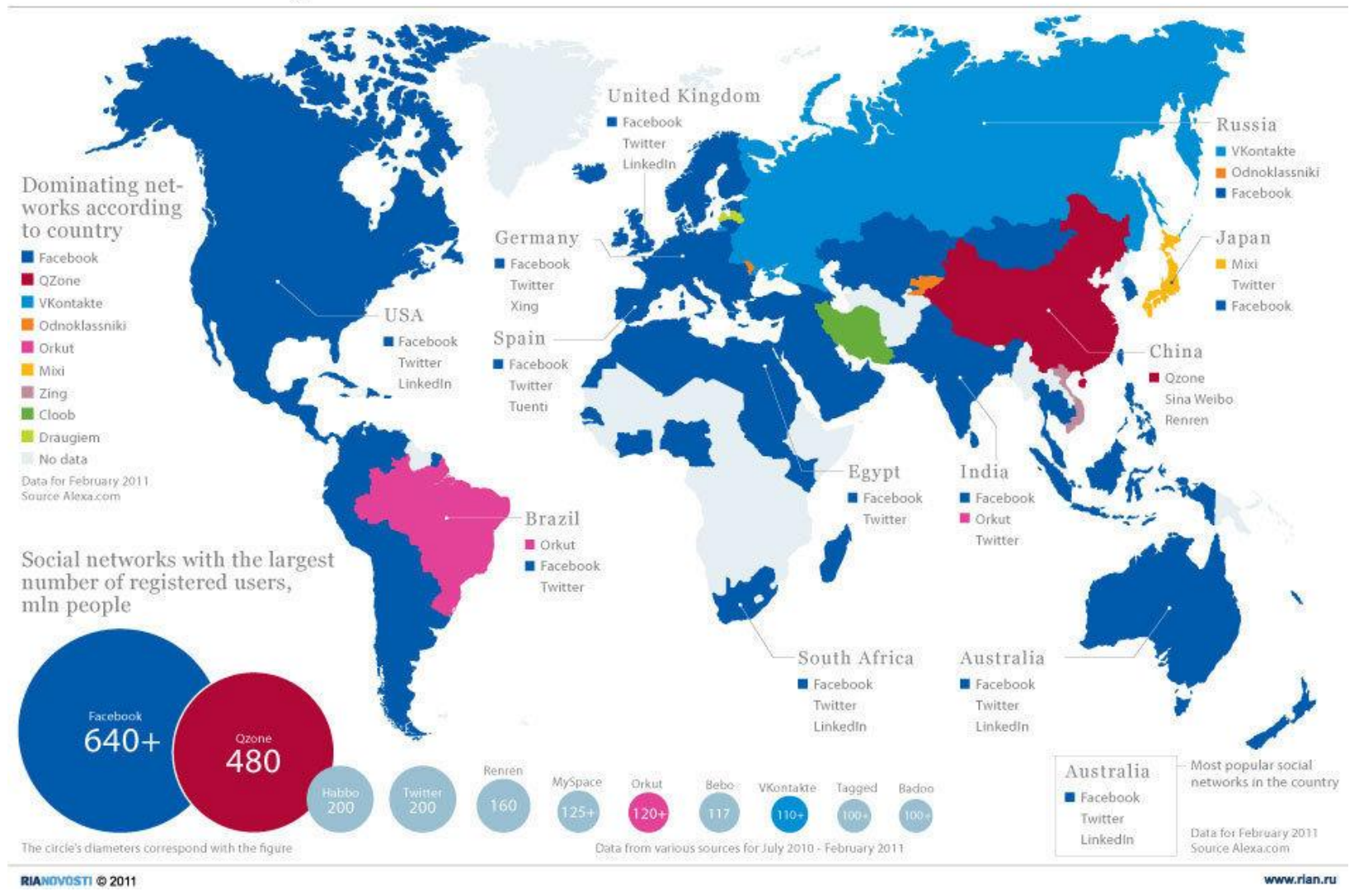

Figure 1: World map of social networks

Source:http://reface.me/wp-content/uploads/world-map-of-social-networks.jpg

OSNs are being progressively used in Egypt, Facebook in particular. Egypt ranked to be number 15 in using Facebook worldwide with 36,881,374 users in 2014. The total number of Facebook users in the Arab world in May 2014 is 81,302,064 up from 54,552,875 in May 2013 with 49\% growth percentage which represents a very significant growth rate. By May 2014 the average for Facebook penetration in the Arab region was over $21.5 \%$ up from $15 \%$ in May 2013. Egypt continues to constitute about $24 \%$ of all Facebook users in the Arab region. These numbers illustrated the huge increase in the number of Facebook users which must be considered by tourism companies (The Arab social media report, 2015).

Table 1 illustrates tourism websites visits via social media referrals provided by Google Analytics. The figure shows that Facebook is the most frequently used social network. 
Table 1: Social network referrals, Source: Google Analytics, 2013.

\begin{tabular}{|c|c|c|c|c|}
\hline Social Network & Visits & Pageviews & Avg. Visit Duration & Pages / Visit \\
\hline 1. Facebook & 251 & 370 & 00:01:18 & 1.47 \\
\hline 2. TripAdvisor & 60 & 236 & 00:03:10 & 3.93 \\
\hline 3. YouTube & 43 & 135 & $00: 04: 43$ & 3.14 \\
\hline 4. WikiAnswers & 22 & 26 & 00:00:04 & 1.18 \\
\hline 5. Facebook Apps & 11 & 12 & 00:00:03 & 1.09 \\
\hline 6. Yahoo! Answers & 11 & 11 & 00:00:00 & 1.00 \\
\hline 7. Draugiem.lv & 10 & 17 & $00: 04: 41$ & 1.70 \\
\hline 8. Flickr & 8 & 9 & 00:00:05 & 1.12 \\
\hline 9. LibraryThing & 7 & 8 & 00:00:03 & 1.14 \\
\hline 10. WordPress & 4 & 4 & $00: 00: 00$ & 1.00 \\
\hline
\end{tabular}

\section{Methodology}

The data analyzed in this study were provided from the secondary data generated by Google Analytics (GA). This research will focus on studying the Website of "Memphis Tours" as part of the situation analysis in order to get insights about the traffic to the Website.

Visits are one of the most basic metrics and a starting point for analysis. According to Opentracker (2013), visits are explained as "happen when someone or something (robot) visits your site. It consists of one or more page views/ hits. One visitor can make multiple visits to your site".

Visits can give general insights into the Website traffic. Social Visitors Flow: Compare traffic volumes and visitor traffic patterns through the site.

The time frame spans one year (from $11^{\text {th }}$ October 2012 to $11^{\text {th }}$ October 2013). The sample can be considered quite significant, even if a single source of data was used. The data collected consisted of the series of total visits of Egyptian websites and the contributions of these visits via social media referrals. Visits can be a good indicator of the behavior of websites with respect to its popularity (Dhyani et al., 2002; Polanco, 2003).

The global series of total visits of websites is an example of cross-sectional series (Sayrs, 1989): a time series consisting of the linear composition of a number of different contributions. In order to access these contributions to the total visits series a multiple regression can be used. This technique is well known and has been widely used in many other studies (Beck, 2008). In addition, testing for multicollinearity have been also used to test that the independent variables are not highly correlated with each other which may hinder the estimation of the effects of individual predictors. The significance of the explanatory variable visits via social media referrals was addressed with a multiple regression as well as the time period. 
Moreover, test for normality of residuals are also performed. To forecast the total number of visits to the tourism websites the time series analysis approach as a non causal method has been used. Forecasting measures of accuracy will be tested using the mean absolute percentage error (MAPE). All analyses have been carried out with SPSS version 18.

The multiple regression approach mathematically simulates cause and effect relationships. Determining the explanatory variables that affect the variable under study and the appropriate mathematical expression of this relationship will be the central objective. This method has an advantage over time series methods of explicitly portraying cause and effect relationships which may be a crucial in certain forecasting situations (Frechtling, 2001).

\section{Results}

The time series for total Egyptian tourism websites visits and visits via social referrals component are shown in figure 2. It can be noticed that the maximum values for the contributions of social referral visits are recorded in the August of year 2013.

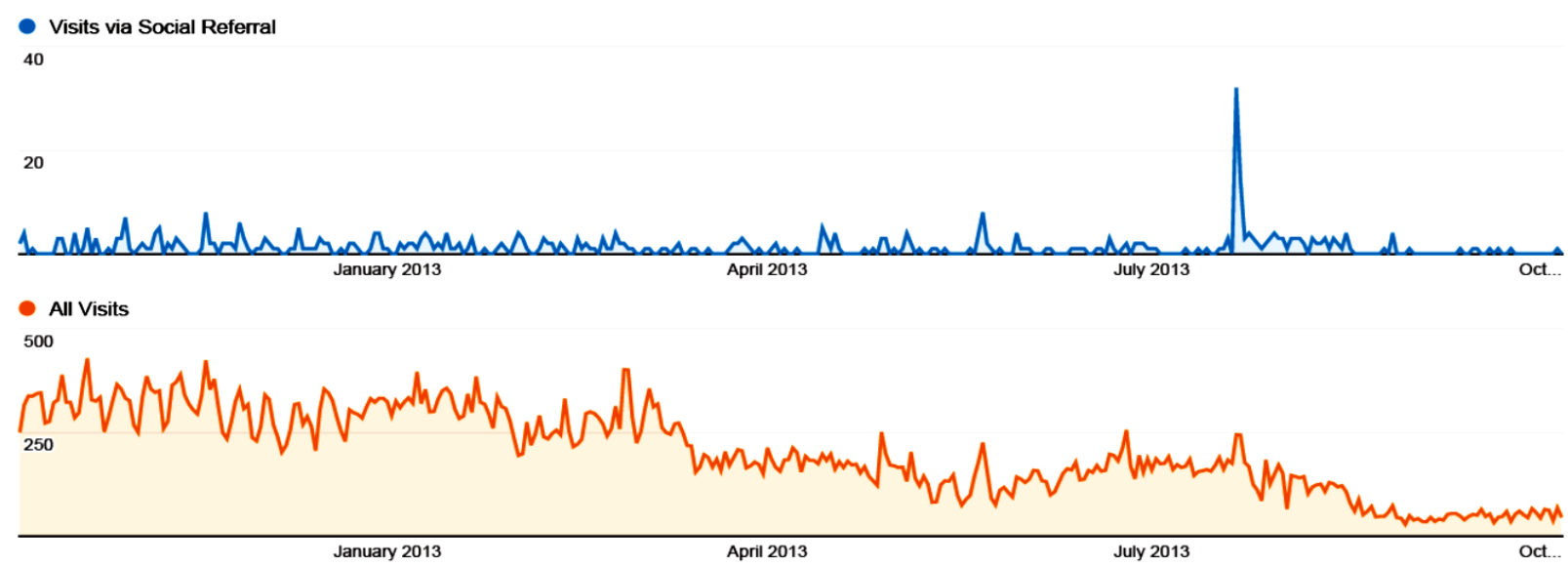

Figure 2: Comparison between total visits and social media referrals. Source: Google Analytics, 2013.

The social media overview report shows that the total visits for a year span accounted for 74,858 while visits via social media platforms accounted for 459 visits, contributing by 2 conversions with $\$ 2.00$ value of total 412 site conversions ( $\$ 412.00$ of total value).

The multiple regression uses the following model (Time is the time period number):

$$
\text { Totalwebsitesvisits }=\text { Constant }+\beta_{1} \text { time }+\beta_{2} \text { socialmediareferrals }+e
$$


Table 2: Results of the multiple regression analysis

\begin{tabular}{|c|c|c|c|c|c|c|c|}
\hline \multirow[t]{2}{*}{ Predictor } & \multicolumn{2}{|c|}{ Coefficients } & \multirow[t]{2}{*}{ t- value } & \multirow[t]{2}{*}{ p-value } & \multicolumn{2}{|c|}{ Collinearity Statistics } & \multirow{2}{*}{$\begin{array}{l}\text { Condition } \\
\text { Index }\end{array}$} \\
\hline & $\beta$ & Std. Error & & & Tolerance & VIF & \\
\hline Constant & 8.846 & .091 & 97.329 & .000 & & & 1.000 \\
\hline Time & -.002 & 0.000 & -4.563 & .000 & .999 & 1.001 & 2.502 \\
\hline social media referrals & .016 & .010 & 2.123 & 0.03 & .999 & 1.001 & 4.608 \\
\hline
\end{tabular}

Results of the multiple regression analysis are displayed in table 2. The explanatory variables are shown with their standard errors and statistical significance. The p- values of Time and social media referrals (less than 0.05) indicating that these two variables significantly affect total websites visits. The coefficient of determination (R-Square $-\mathrm{R}^{2}$ ) is the proportion of variance in the dependent variable which can be explained by the independent variables. The R-square value is .382 which indicates that our independent variables explain only $38.2 \%$ of the variability of the dependent variable. This is considered providing an acceptable fit. Residuals are normally distributed, a KolmogorovSmirnov (K-S) test produces $\mathrm{Z}$ equals 0.768 which has an asymptotic p-value equals 0.324 (The K-S test has a null hypothesis of normality). The multicollinearity diagnostic by checking the condition index does not show any problems.

The $F$-ratio in the ANOVA illustrated in table 3 tests whether the overall regression model is a good fit for the data. The table shows that the independent variables statistically significantly predict the dependent variable as $F=11.731, p<.0005$ (i.e., the regression model is a good fit of the data).

Table 3: ANOVA results

\begin{tabular}{|c|l|l|l|l|l|}
\hline Model & Sum of Squares & Df & Mean Square & F & Sig. \\
\hline \multirow{2}{*}{ Regression } & 12.009 & 2 & 6.004 & 11.372 & \\
Residual & 176.881 & 335 & .528 & & $.000^{\mathrm{b}}$ \\
Total & 188.890 & 337 & & & \\
\hline
\end{tabular}

SPSS is also used to forecast the time series of the total websites visits. The nonseasonal autoregressive- moving average model (ARIMA) is used to forecast the total websites visits. The sample autocorrelation (SAC) and the partial sample autocorrelation (SPAC) were used to identify the model as illustrated in figure 3. The behavior of (SAC) and (SPAC) of the time series of the total websites visits indicated that the model is ARIMA $(0,0,4)$ provides the best forecast for the time series for the total websites visits (meaning autoregressive operator $(\mathrm{AR})=[0]$ difference $(\mathrm{DIFF})=[0]$ moving average $(\mathrm{MA})=[4])$. 
Table 4: Results of the ARIMA model of the total websites visits

\begin{tabular}{|l|l|l|l|l|l|l|}
\hline \multicolumn{2}{|l|}{ Model Fit statistics } & \multicolumn{3}{l|}{ Ljung-Box Q(18) } \\
\hline Stationary R-squared & R-squared & MAE & MAPE & Statistics & DF & Sig. \\
\hline .192 & .192 & .560 & 6.845 & 21.335 & 14 & .093 \\
\hline
\end{tabular}

The mean absolute percentage error (MAPE) equals 6.845 which means that this model provide accurate forecast (Shmeli, 2011). Moreover, the Ljung-Box is used to test the adequacy of the overall model. If the probability- value is greater than 0.05 , (p-value $=$ $0.093>0.05$ ) then it is reasonable to conclude that the model is adequate and it can be used to forecast the total websites visits.

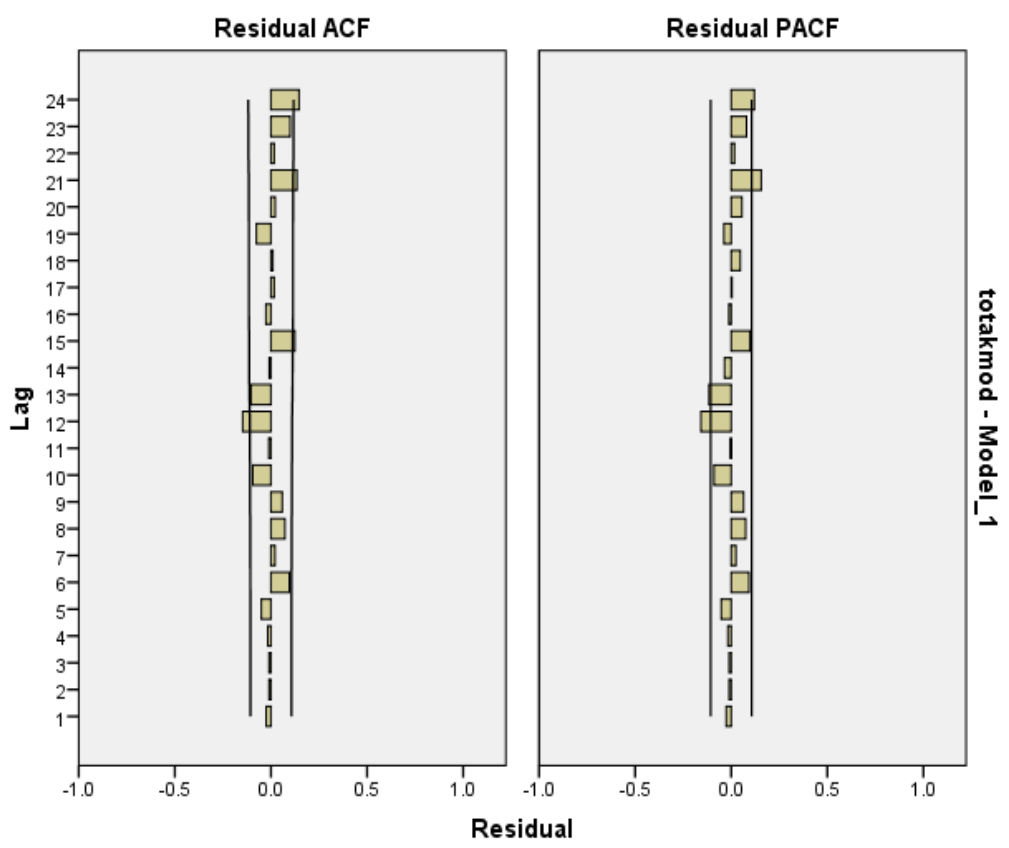

Figure 3: The autocorrelation function and the partial autocorrelation function of the total websites visits

In addition, the social referrals are then forecasted using the nonseasonal autoregressive- moving average model (ARIMA). The sample autocorrelation (SAC) and the partial sample autocorrelation (SPAC) were used to identify the model as illustrated in figure 4. The behavior of (SAC) and (SPAC) of the time series of the total websites visits indicated that the model is ARIMA $(1,1,1)$ provides the best forecast for the time series for the total websites visits (meaning autoregressive operator $(\mathrm{AR})=[1]$ difference $(\mathrm{DIFF})=[1]$ moving average $(\mathrm{MA})=[1])$. 
Table 5: Results of the ARIMA model of the total websites visits via social media referrals

\begin{tabular}{|l|l|l|l|l|l|l|}
\hline \multicolumn{2}{|l|}{ Model Fit statistics } & \multicolumn{2}{l|}{ Ljung-Box Q(18) } \\
\hline Stationary R-squared & R-squared & MAE & MAPE & Statistics & DF & Sig. \\
\hline .084 & .860 & .811 & 23.449 & 10.657 & 16 & .830 \\
\hline
\end{tabular}

The mean absolute percentage error equals 23.449 which mean that the suggested model provides acceptable forecast (Shmeli, 2011). Furthermore, the Ljung-Box is used to test the adequacy of the overall model. If the probability- value is greater than 0.05 , (pvalue $=0.0 .830>0.05)$ then it is reasonable to conclude that the model is adequate and it can be used to forecast the total websites visits via social referrals.

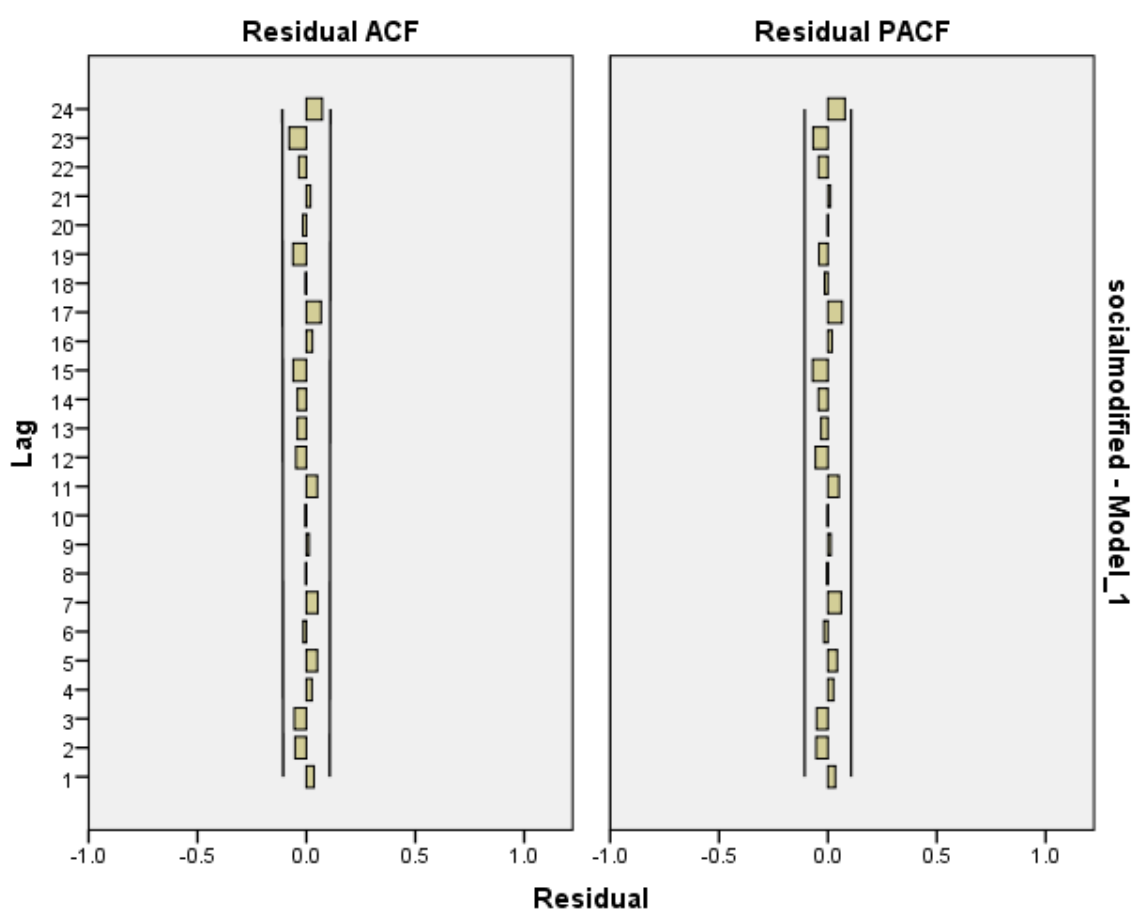

Figure 4: The autocorrelation function and the partial autocorrelation function of social media referrals

\section{Discussion}

The results of the study indicated that the contributions of the social media are of a low level. A higher contribution would have been expected, particularly with the increasing usage of social media as illustrated, but this result is in agreement with other studies such as Milano et al., 2011; Hamill et al., 2009 and Schegg et al., 2008. The analysis shows that both time and visits via social media referrals have a significant effect on total websites visits. It provides simple and effective method to measure the significance contribution of different explanatory variables in a dependent variable (total number of visits to a tourism websites in the present study). Furthermore the overall regression 
model is a good fit for the data. Hence the regression model can be used to forecast the total websites visits. In addition, it can be used by managers and marketers to simulate the various probable changes in the social media users either in number or characteristics and its influence on the total number of visits to Egyptian tourism websites.

The growth of the facebook users reaches $22 \%$ from 2012 to 2013 (StatisticsBrain, 2015), which represents a remarkable increase, indicating that there is very significant increase in the use of social media which must be considered by those who are responsible of tourism websites to exploit this phenomenon.

In addition, forecasting the time series of the total websites visits using ARIMA provides an accurate forecast $(\mathrm{MAPE}=6.845)$. Hence, this forecasting method can be used to forecast the total websites visits at least in the short term. This result can be useful to tourism and hospitality businesses as it helps them to identify the potential resources and efforts which may be granted to enhance their websites. Moreover, the time series of the total websites visits does not show any seasonal variations. This results means that the participation in the Egyptian tourism websites does not show any seasonal evidence, and this subsequently could lead to an important conclusion that although tourism in Egypt suffer from seasonality, total tourism websites visits does not show this pattern. This result further should be addressed by Egyptian tourism businesses as they should maintain their effective presence and participation in the social media all the year not only in the peak season. In addition, they should maximize their efforts to either establish a website for those who do not have a website or enhance it for those who are already had a website as the growth rate is ultimately huge.

\section{Conclusion}

The main objective of this study was to investigate the contribution of online social networks on the total visits of tourism websites. The results show that time and social media referrals have a significant influence on the total visits of tourism websites. This relation must be exploited by responsible on tourism websites to increase their presence and activity in online social networks to increase the benefit of this result, where results indicate low contribution of these features on tourism websites examined.

In addition, the study shows that ARIMA as a time series forecasting method can be considered an accurate method to forecast total tourism websites visits in Egypt. This result could be exploited by managers to predict the total tourism websites visits in Egypt to better allocate resources and efforts.

The study also illustrated the increasing diffusion of ICTs and Web 2.0 in today's life. This will subsequently has a significant effect on tourism industry. Thus, these increasing trends will represent a big challenge to tourism business. Lack of resources, low technical competence and lack of awareness of the importance of ICT's in tourism business are the main obstacles facing the effective adoption of ICT's by tourism companies.

Furthermore, it can be concluded that the increasing trends in using OSN should be met by a rapid move by tourism businesses to develop their competitiveness, where the success of a business, to certain extent, depends on its ability to obtain and utilize updated information to assist its management and marketing processes. The use of Facebook as a marketing channel is a very interesting but little studied topic. More and more companies are joining Facebook and the rest are on their way to join and participate on social media. 
Tourism companies must be more active, adding more pictures and videos as well as posting status updates on their wall. They should also give their customers option to start discussions and write reviews. In addition, they should also consider updating their websites as well as their social media-site frequently and regularly. It is very important to put much effort into their social media- presence.

Tourism companies should cooperate together to overcome the weakness and deficiencies facing the effective adoption of ICT's and effective presence on Web 2.0 to strengthen its effect.

Finally, Egyptian tourism businesses should not only consider the presence and interaction on Facebook, Google+ and My space, they should also consider Media sharing platforms such as You Tube and Pinterest. For businesses, using media sharing platforms provide an opportunity to reach a large audience and facilitate posting, tagging and organization of the visual content.

Future research should address the media sharing platforms such as Pinterest as it should be of interest for marketers in the tourism industry. This can be confirmed by the popularity of many travel brands available on Pinterest.

\section{References}

- Akehurst, G. (2009). "User generated content: The use of blogs for tourism organizations and tourism consumers". Service Business, Vol.3, No. 1, pp. 51-61.

- Beck, N. (2008). "Time series cross section methods". In Box- Steffensmeir, H. Brady and D. Cllier (Eds.). The Oxford Handbook of Political Methodology, pp. 475-493. Oxford: Oxford University Press.

- Blackshaw, P. (2006). "The Consumer-Generated Surveillance Culture". Available online from http://www.clickz.com/showPage.html?page=3576076 [Accessed April 2015]

- Buhalis, D. (1998). "Strategic Use of Information Technologies in the Tourism Industry". Tourism Management, Vol. 19, No. 3, pp. 409-423.

- Buhalis, D. (2003), "E-Tourism: Information Technology for Strategic Tourism Management”. Cambridge. Pearson.

- Buhalis, D., and O’Connor, P. (2005). "Information Communication Technology Revolutionizing Tourism”. Tourism Recreation Research, Vol. 30, No. 3, pp. 7-16.

- Casalo, L., Flavian, C. and Guinaliu, M. (2010). "Understanding the intention to follow the advice obtained in an online travel community". Computers in Human Behavior. In press.

- CBI, (2007). Country Brand Index. New York: FutureBrand. Retrieved February, Available online from http://www.futurebrand.com [Accessed May 2015]

- Charlesworth, A. (2009). "Internet marketing: A practical approach". Amsterdam: Elsevier ButterworthHeinemann.

- Connolly, D. J., and Lee, S. (2006). "Developing Information Technology Proficiencies and Fluency in Hospitality Students". Journal of Hospitality and Tourism Education, Vol. 18, No. 3, pp. 15-29.

- Conzenza, V. (2010), "World map of social networks". Available online from http://www.vincos.it/world-mapof-social-networks/. [ Accessed May, 2015]

- Corfu, A., \& Kastenholz, E. (2005). "The Opportunities and Limitations of the Internet In Providing A Quality Tourist Experience: The Case of "Solares De Portugal". Journal of Quality Assurance in Hospitality and Tourism, Vol. 6, No. 1/2, pp. 77-88.

- Cormode, G. and Krishnamur, B. (2008). "Key Differences between Web 1.0 and Web 2.0”.Available onlina from http://citeseerx.ist.psu.edu/viewdoc/download?doi=1 0.1.1.145.3391 \&rep=rep I\&type=pdf [Accessed May 2015].

- Dellarocas, C. (2003). "The digitization of word-of-mouth: promise and challenges of online feedback mechanisms". , Vol.49, No. 10, pp. 1407-1424.

- Dhyani, D., Ng, W.K., and Bhwmick, S. S. (2002). "A survey of web metrics. ACM Computing Surveys, Vol. 
- 34, No. 4, pp. 469-503.

- Dooley, A. J., Jones, S. C. and Iverson, D. (2012). "Web 2.0: An assessment of social marketing principles". Journal of Social Marketing, Vol. 3, No. 2, pp. 207-221.

- D. C. Frechtling (2001). "Forecasting Tourism Demand: Methods and strategies". Butterworth-Heinemann, Oxford, London.

- eMarketer (2012). "Social media - a sample of eMarketer's topic coverage". Available online from https://www.emarketer.com/Coverage/SocialMedia.aspx. [Accessed June 2015]

- Ettestad, S. (2008). "Easy travel 2.0 strategies hotels can implement Today”. Hospitality Upgrade, p.172.

- Gillin, P. (2009). "Secrets of social media marketing. How to use online conversations and customer communities to turbo-charge your business". Fresno: Quill Driver Books.

- Gretzel, U. (2006). "Consumer-Generated Content - trends and implications for branding". EReview of Tourism Research,Vol. 4, No. 3, pp. 9-11.

- Hamill, J., Attard, D. and Stevenson, A. (2009). "National destination marketing organizations and Web 2.0. Mercati e Competitivita, Vol. 1, pp. 71-94.

- Han, J. and Mills, J. (2006)."Zero acquaintance benchmarking at travel destination websites: what is the first impression that national tourism organizations try to make?" International Journal of Tourism Research,Vol. 8, No.6, pp. 405-430.

- Han, J.and Mills, J. (2007). “Are Travel Websites Meeting the Needs of the Visually Impaired?" Information Technology and Tourism, Vol. 9, No. 2, pp. 99-113.

- Ho, C., and Liu, Y. (2005). “An Exploratory Investigation of Web-Based Tourist Information SearchBehavior”. Asia Pacific Journal of Tourism Research, Vol. 10, No. 4, pp. 351-360.

- Inside Facebook, Available online http://www.insidefacebook.com/2015/03/02/facebook-acquires-social-travelstartup-nextstop/. [Accessed April 2015]

- Internet World Statistics. Available online from http://www.internetworldstats.com/stats.htm. [Accessed April 2015]

- Inversini, A., Eynard, D., Marchiori, E., \& Gentile, L. (2012). Destinations similarity based on user generated pictures' tags. In M. Fuchs, F. Ricci, \& L. Cantoni (Eds.), Information and communication technologies in tourism 2012 (pp. 483-493). Wien: Springer.

- Ip C, Law R, and Lee HA (2011)."A review of website evaluation studies in the tourism and hospitality fields from 1996 to 2009”. International Journal of Tourism Research,Vol. 13, No. 3, pp. 234-265.

- Kale, S. H. (2006). "Designing Culturally Compatible Internet Gaming Sites". UNLV Gaming Research and Review Journal, Vol. 10, No. 1, pp. 41-50.

- Kamuzora, F. (2006). "An Investigation into Web Analytics in Marketing Tanzanian Tourist Products: Managing without Measuring". Consortium Journal of Hospitality and Tourism, Vol. 11, No. 1, pp. 17-24.

- Kaplan, A. M., and Haenlein, M. (2010). "Users of the world, unite! The challenges and opportunities of social media". Business Horizons, Vol. 53, pp. 59-68.

- Kim S, Fesenmaier DR (2005). "Persuasive designs of tourism websites in the United States". In: Proceedings the 36th annual conference of Travel Tourism Research Association. Boise Travel and Tourism Research Association.

- Kim, W. G., and Ham, S. (2007). "The Impact of Information Technology Implementation on Service Quality in the Hotel Industry". Information Technology in Hospitality, Vol. 4, No. 4, pp. 143 - 151.

- Klausegger, C. (2005). "Evaluating Internet Portals: An empirical study of acceptance measurement based on the Austrian National Tourist Office's Service Portal”. Journal ofQuality Assurance in Hospitality and Tourism, Vol. 6, No. (3/4), pp. 163-183.

- Kluemper, D. and Rosen, P. (2009), "Future employment selection methods: evaluating social networking web sites”. Journal of Managerial Psychology, Vol. 24, No. 6, pp. 567-580.

- Law, R., and Huang, T. (2006). "How Do Travelers Find their Travel and Hotel Websites?". AsiaPacific Journal of Tourism Research, Vol.11, No. 3, pp. 239-246.

- Law, R., Chan, I., and Goh, C. (2007). "Where to Find the Lowest Hotel Room Rates on the Internet? The Case of Hong Kong”. International Journal of Contemporary HospitalityManagement, Vol. 19, No. (6/7), pp. 495-506.

- Law R, Leung R, and Buhalis, D. (2009)."Information technology applications in hospitality and tourism: a review of publications from 2005 to 2007'. Journal of Travel and Tourism Marketing, Vol. 26, No. 5-6, pp. 599-623. 
- Litvin, S. W., Goldsmith, R. E., and Pan, B. (2008). "Electronic word-of-mouth in hospitality and tourism management". Tourism Management, Vol. 29, pp. 458-468.

- Maurer, C. and Hinterdorfer, B. (2014). " The Adoption of Pinterest for Destination Marketing: The Case of Austrian Destinations". In Z. Xiang and I. Tussyadiah (eds.), Information and CommunicationTechnologies in Tourism 2014. Springer International Publishing, Switzerland.

- Michelis, D., and Schildhauer, T. (2012). "Social Media Handbook". Baden-Baden: Theorien, Mehoden, Modelle und Praxis Nomos.

- Milano, R., Baggio, R. and Piattelli, R. (2011). "The effects of online social media on tourism websites". In R. Law, M. Fuchs and F. Ricci (Eds). Information and Communication Technologies in Tourism 2011. SpringerWein- New York. pp.471- 483.

- Murphy, J., Hofacker, C. F., and Racine, Y. (2006). "Testing Position Effects and Copy to Increase Web Page Visits". Information Technology and Tourism, Vol. 8, No. 1, pp. 3-13.

- O’Connor, P. (1999), "Electronic Information Distribution in Tourism Hospitality”. Oxford. CABI.

- O'Connor, P. (2003). "Room rates on the Internet-Is the web really cheaper". Journal of Services Research, Vol. 1, No. 1, pp. 57-72.

- Open tracker, (2013), Available Online from http://www.opentracker.net [Accessed June 2015].

- O'Reilly, T. (2007). "What is Web 2.0: Design patterns and business models for the next generation of software".Available online from http://papers. ssrn.com/ so 13/papers.cfm ?abstract_id= I 008839[Accessed February, 2015]

- Parker, R. D. (2012). "The evolving dynamics of social media in internet tourism marketing". Journal of Tourism Research and Hospitality, Vol. 1, No. 1, pp. 1-2.

- PhoCusWright (2009). "The PhoCusWright consumer technology survey, $2^{\text {nd }}$ ed. Sherman, CT: PhoCusWright.

- Polanco, X. (2003). "Concepts, measures and indicators in the Web analysis". Paper presented at the Tercer Taller de Obtencion de indicators de produccion cientifica, Madrid, March 3-5. Available online from http://www.ricyt.org/interior/normalizacion/III_bib/Polanco.pdf.[ Accessed February, 2015]

- Reactive (2007). "Web 2.0 for the Tourism and Travel Industry". A White Paper. Reactive MediaPty Ltd. Available online from http://blogs.reactive.com [Accessed 2015].

- Sayrs, L. W. (1989). "Pooled time series analysis". Newbury Park, CA: Sage.

- Schegg, R., Liebrich, A., Scaglione, M. \& Ahmed, S.F.S. (2008). "An exploratory field study of Web 2.0 in tourism. In O’Connor, W. Hopken \& U. Gretzel (Eds), Information and Communication Technology in Tourism 2008 (pp. 152-163). Wien: Springer.

- Schmidt S, Cantallops, AS., and dos Santos, C.P. (2008). "The characteristics of hotel websites and their implications for website effectiveness". International Journal of Hospitality Management,Vol. 27, No.4, pp. 504-516.

- Shi, Y. (2006). "The Accessibility of Queensland Visitor Information Centres' Websites". Tourism Management, Vol. 27, No. 5, pp. 829-841.

- Shmeli, G. (2011). "Practical time series forecasting: A hands- On guide", $2^{\text {nd }}$ edition, (Practical Analytics), Kindle edition, Axefrod Schnall Publishers.

- Sigala, M. (2010). "eCRM 2.0 applications and trends: The use and perceptions of Greek tourism firms of social networks and intelligence". Computer in Human Behavior, (In Press, DOI: 10.1016/j.chb.2014.11.08).

- Singh, A. J., and Kasavana, M. L. (2005). "The Impact of Information Technology on Future Management of Lodging Operations: A Delphi Study to Predict Key Technological Events in 2007 and 2027'. Tourism and Hospitality Research, Vol. 6, No.1, pp. 24-37.

- Singh, A. J., Kim, H., and Huh, C. (2006). "Differential Impacts of Information Technology Services in the Korean Hotel Industry: A Study of Management Perceptions”. FIU HospitalityReview, Vol. 24, No. 2, pp. 7889.

- Statistic Brain. (2014). Social networking statistics. Available online from: http://www.statistics brain.com/facebook-statistics/ [Accessed May 2015].

- The Arab social media report (2015). Available online from http://www.arabsocialmedia report/Facebook/LineChart.aspx [Accessed June 2015].

- The Gallup organization (2015). Available online from http://www gallup.com/home.aspx [Accessed May 2015]

- The Statistics Portal. Available online from http://www.statista.com/statistics/278424/number-of-worldwidesocial-network-users/ [Accessed June 2015]

- TlA. (2008). "Travelers' Use of the Internet". Washington D.C.: Travel Industry Association of America.

- Tuten,(2008). "Advertising 2.0: Social media marketing in a web 2.0 world". Westport: Praeger Publisher. 
- Utkarsh, D.D.G. (2014). "Assessing the website effectiveness of top ten tourist attracting nations". Information Technology in Tourism, Vol.14, No. 151-175.

- Warnaby G., White G. R., Prabhakar G. P., and Abd Razak A.(2008). "Adoption and Use of E-commerce by Small Businesses in the UK Tourism Industry". In: Entrepreneurship and Firms in the New Economy, Tunisia, 2008.

- Werthner, H., and Klein S. (1999).“Information technology and tourism—a challenging relationship”. Springer, Wien.

- Werthner, H., Alzua-Sorzabal, A., Cantoni, L. Dickinger, A., Gretzel, U., Jannach, D. Neidhardt, J., Pro, B., Ricci, F., Scaglione, M., Stangl, B., Stock, O. and Zanker, M. (2015). "Future research issues in IT and tourism: A manifesto as a result of the JITT workshop in June 2014", Vienna, Information and Technology in Tourism,Vol.15, No. 1-15.

- Williams, R., and Rattray, R. (2005). "UK Hotel Web Page Accessibility for Disabled and Challenged Users". Tourism and Hospitality Research, Vol. 5, No. 3, pp. 255-267.

- Williams, R., Rattray, R., and Grimes, A. (2006). "Meeting the On-Line Needs of Disabled Tourists: An Assessment of UK-Based Hotel Websites". International Journal of Tourism Research, Vol. 8, No. 1, pp. 59-73.

- Winata, L., and Mia, L. (2005). "Information Technology and the Performance Effect of Managers' Participation in Budgeting: Evidence from the Hotel Industry". International Journal of Hospitality Management, Vol. 24, No.1, pp. 21-39.

- Xiang, Z., Wöber, K., and Fesenmaier, D. R. (2008). "Representation of the onlinetourism domain in search engines". Journal of Travel Research, Vol. 47, No. 2, pp. 137-150.

- Xiang, Z. and Gretzel, U. (2010). "Role of social media in online travel information search". Tourism Management, Vol. 31, No. 2, pp. 179- 188. 